\title{
The ideology of friendship in the era of Facebook
}

\author{
Daniel Miller, University College London
}

This article suggests that while anthropologists have developed a highly nuanced analysis of kinship and friendship under a more general comparative study of relationality, this emphasis upon practice needs to be complemented by an alternative focus on the use of these terms as ideology, where we find a more simplistic and dualistic usage. The rise of new social media and the verb friending highlights a more general shift from the idea of fictive kinship to that of fictive friendship, where it is the ideals represented by the supposed voluntarism and authenticity of friendship that has now come to dominate the way people view kin relations. Evidence is provided from ethnographies in the Philippines, Trinidad, and England that illustrate the prevalence of a practice where kin relations reposition themselves under the idiom of friendship with both negative and positive consequences. This incorporation of kinship within friendship can also bring back a sense of rule and obligation, which has led to a decline in the use of Facebook by the young.

Keywords: friendship, social media, kinship, Facebook, England

\section{Meanwhile in South Park}

Stan is reluctantly dealing with a Facebook profile that his friends created for him despite his not wanting to have anything to do with Facebook.

Stan edits profile: Basic settings ... Jesus Christ!

Stan's Dad appears at the door looking stern.

Dad: Stan, why won't you be friends with Grandma?

Stan: Oh Dad, I just really don't want to pay attention to this thing.

Dad: Grandma is in the hospital, and you won't even be friends with her?

Stan: All right, Dad. I will add Grandma as a friend.

Dad: That's better. Oh, and I sent you a funny picture and you didn't respond to it. — "You Have 0 Friends," South Park, first aired April 7, 2010 
In journalistic discourse, social media, and especially Facebook, has been seen as part of a shift toward self-absorbed individualism and untrammelled self-expression exemplified by perhaps the most iconic form of posting: the "selfie." But the writers of South Park have a rather deeper and generally more accurate sense of something quite different. Nothing here reflects the agency of the hapless Stan. He doesn't want to be on Facebook, it is his friends who create his profile. Several of my informants in Trinidad were initially aghast when they realized that although they had never joined Facebook, thanks to tagged photographs and the activities of others, they had quite an active presence on the social media platform over which they had no control. They could at least influence the way they were being represented only by acquiescing to the wider population and creating a profile themselves. Even for the majority of Facebook users, the images most people like to look at are tagged photos placed there by others rather than the ones carefully created and selected oneself. It is as though other people dress you to go out in public. So even if we have not joined Facebook, we all live now in the era of Facebook (or its Chinese equivalents).

But forcing Stan to be on Facebook comes earlier in the episode. At this stage we might expect he would be interacting with friends. But in this extract, the people who have imposed themselves on Stan are Dad and Grandma: people he is told he has an obligation to friend and respond to because they are kin. Yet, at the same time the verb used is to friend Grandma, a verb we now closely associate with Facebook itself.

For anthropologists this raises a series of core questions. What is the contemporary meaning of friendship that is being exploited in this way by Facebook? How does the sense of obligation-which is clearly conflated with kinship here-correspond to contemporary anthropological and colloquial ideas about kinship? Taken at face value the extract from South Park implies that Stan is being ordered to subsume kin under the idiom of friending. Does this constitute a kind of "fictive friendship" on analogy with an older discussion in anthropology about "fictive kinship?" In which case, how general is this and what would be the consequences?

The study of fictive kinship was first established in the late 1950s (e.g., Norbeck and Befu 1958; Okada 1957). As Stanley Freed noted (1963), this could be a relatively informal and indeterminate type of metaphorical relation, but it could also be found as a highly structured and systematic addendum to other forms of kinship relation. At that time, most students would have had some experience of being engaged in that practice through the use of titles such as "Auntie" and "Uncle" as honorific with respect to various friends of their parental and grandparent generations. In many parts of the world this remains common. As a result, the idea of fictive kinship was widely accepted and is now used in many studies outside of anthropology, ranging from peer terms among adolescents (Tierney 2006) through to the study of ageing (Mac Rae 1992).

Since that time, however, we have seen the rise of a much more grounded study of friendship that would challenge the simple dualism with kinship implied by the term fictive kinship. This is best summarized by two edited volumes, The anthropology of friendship (Bell and Coleman 1999b) and The ways of friendship 
(Desai and Killick 2010). These volumes have pointed out the prior neglect of friendship as a topic, and the importance of contextualizing friendship through comparative studies. It is still possible to define kinship in relation to, for example, consubstantiality (Dousset 2013) or mutuality (Sahlins 2011) in a manner that would not presume these qualities within friendship but in general, friendshipas-kinship is now subsumed by anthropologists under a more general and comparative study of relationality. This conflation of kinship and friendship brings out wider underlying parameters such as the nature of relatedness and sociality, as well as the continued spectrum from more formalized and ritual structures (e.g., Desai 2010) through to ideals of informality, voluntarism, and sentiment in friendship formation. Studies demonstrate that societies had ideals of voluntarism and choice in friendship prior to any association with modernity, such as among the Mapuche of Chile (Course 2010). Others have stressed the importance of seeing friendship in its own terms and as having alternative foundations, for example, in proximity (Froerer 2010), and not merely viewing friendship through its relationship to or opposition from kinship (Killick and Desai 2010).

There are clear parallels with the study of kinship and friendship in sociology, for example, as applied to the British context where concepts such as Families of choice (Weeks, Heaphy, and Donovan 2001) and the work of Janet Finch and Jennifer Mason (1993) were highlighting the contribution of voluntarism and pragmatism also within contemporary British kinship. Similar discussions followed from the work of Ulrich Beck (Beck and Beck-Gernsheim 1995), but especially that of Anthony Giddens. Giddens promulgated an idea of the "pure relationship," arguing that there has been a shift in the ideals of couples from obligation to negotiation, with changes in the status of love and commitment (1991: 88-98). Giddens' ideas gained their grounding from a series of prior sociological studies that showed such a transformation in English ideals, for example, Michael Young and Peter Willmott's study of The symmetrical family (1975), characterized by sharing and negotiation. Others, especially Graham Allan (1979, 1989) and Ray Pahl (2000), have shown how the same period marks a new blurring of boundaries in Britain between kinship and friendship. Much of this is prefigured by the earlier work of Raymond Firth on kinship in London (1956), who argued that in practice bilateral kinship was treated as something of an option, thereby transcending any simple dualism between voluntarism and obligation.

The primary force that led to the repudiation of the simple opposition implied by the term fictive kinship derives, however, more from the study of kinship than friendship. Although there are precedents, perhaps the most influential intervention comes with Pierre Bourdieu's (1968) Outline of a theory of practice, which documented such a marked discrepancy between kinship as practice and kinship as a rule as to make it seem that most prior models had ignored key issues of behavior, pragmatism, and selection. From here we see a clear trajectory with many demonstrations of how earlier dualisms fail to accord with practice. These would include the work of John Comaroff and Simon Roberts (1981) in undermining the distinctions between ascription and achievement, Rupert Stasch (2009) on the importance of examining at a more general level the way people experience relationships as the other, through to the highly influential work of Janet Carsten (1997) on viewing kinship as a dynamic process. To summarize, it seems clear that most 
contemporary anthropologists prefer to regard both kinship and friendship as part and parcel of a much more general anthropology of relationality.

If, however, we return to the original argument made by Bourdieu, there are surely two (not just one) potential trajectories that follow from his argument that practice may be highly discrepant from the rule generated by ideology. The most common trajectory is that which has allowed anthropology to develop a more nuanced study of kinship as practice with less concern as to whether it accords with the claims made about how kinship is supposed to operate. But the very same argument must also imply that ideology and the rule are equally autonomous from the changes and vagaries of practice. This suggests that anthropologists are now equally free to study developments in the ideology of kinship even if these remain discrepant from the evidence of kinship as practice. The same point would surely follow for the study of friendship as ideology.

So, it is one thing for anthropologists or indeed sociologists, to have achieved this level of nuance and sophistication in the study of kinship and friendship as practice, but quite another to project this as the meaning of the terms kinship and friendship among the peoples that we study. The rise of new social media and verbs such as friending provide an opportunity to appraise a very different trajectory: the colloquial meaning and the underlying ideology of kinship and friendship as generic concepts. In my own eighteen months of study within an English village, notwithstanding the rise of complexity following the increase in the experience of divorce and stepfamilies, perhaps the single most common expression employing these terms was that "you can choose your friends but you can't choose your relatives." At the level of ideology, it remains axiomatic that friendship is an expression of choice and is thereby opposed to kinship that consists of relationships based on obligation. This was equally evident in our detailed discussions of the impact of social media on both kinship and friendship. These interviews were carried out with over 370 different informants (Miller 2016) and they showed that this cliché does indeed inform the way they understand kinship and friendship more generally.

Later sections of this essay include ethnographic material from both the Philippines and Trinidad. In both field sites I frequently heard the exact same expression-as in England-that "you can choose your friends but you can't choose your relatives," even though there are huge differences in culture, history, and the actual practice of both friendship and kinship. Possibly because of the closer association between ideology, common idioms, and popular culture this seems to have become something of a global sentiment. Our comparative project on social media includes two volumes about China. Xinyuan Wang (2016: 115-20) argues that for rural migrants to factories in China there may have been very little opportunity to develop friendship outside of kinship in the past, so the emphasis on finding friends through social media itself is viewed as the discovery of a new possibility in relationships that is important precisely because it feels so free and modern in its voluntarism and the primary interest of these factory workers is to find new ways to appear modern. These friends now include strangers who are neither kin, nor fellow workers, but simply people that have been met through social media itself. Similarly, the primary thesis of Tom McDonald's (2016: 89-115) volume is that people in a small rural town in China have for the first time developed friendships with strangers directly through social media and are fascinated by the new 
possibilities this kind of friendship represents, compared to forms of relationship that were previously available. Because you may not meet these anonymous people, they can become the basis of quite intimate and confessional relationships. These volumes show how social media such as QQ and WeChat have created the conditions for this same dualism, where kinship represents the obligations traditional of rural sociality, while by contrast, friendship is coming to stand for the modern ideals of choice and voluntarism. This suggests that at the level of ideology the use of these terms kinship and friendship to construct an opposition may be growing rather than diminishing.

All of this suggests that the fact that the Facebook platform has as one of its fundamental components the verb "friending" and that one of the earliest successful social media platforms was called Friendster did not arise by happenstance. These new terminologies reflect a deeper shift in the way kinship and friendship are used as ideological tropes. In practice, much of this "friending" on social media is of kin. In Elisabetta Costa's (2016: 88-94) study of Kurdish lineage and tribal organization, she finds individuals with hundreds of "friends" on Facebook, almost all of whom are actually kin. This phenomenon could be termed fictive friendship analogous with the prior idea of fictive kinship. Fictive friendship is the process by which people try and subsume kinship within a much wider trend toward the idealization of informality, authenticity, and liberal choice as designated modern values (Giddens 1991: 88-98; Lindholm 2013; Misztal 2000). A parallel would be the shift in conventional photography from formal posing to the ideal of informal snapshots of persons who thereby appear "natural" and "authentic."

There is nothing new about considering kinship and friendship as powerful ideological tropes that stand as idioms for much wider values. If we go back to classical sources from Aristotle to Cicero it is already clear that friendship is highly normative (Baltzly and Eliopolous 2009: 1-64). Still today we are commonly dealing with what Robert Paine called "the idealness of friendship" (1999: 41). As anthropologists and sociologists have pointed out, this ideal in recent times has centered increasingly on notions of "autonomy, voluntarism, sentiment and freedom" (Bell and Coleman 1999b: 10). There is a general sense that such connotations provide a bulwark against various structures of oppression and obligation, which can include the feeling that kinship itself has increasingly become a burden or shackle constraining the embrace of modern possibilities in relationality.

There are many factors that may account for the shifting balance from the obligations represented by kinship to the choices idealized as friendship. For example, with regard to the United Kingdom, Mark Peel, Liz Reed, and James Walter (2009) note the impact of the rise of the welfare state and public entitlement as making individuals less dependent on family, which gives them more choice over significant relationships. There is the work of Anthony Heath (1981) on social mobility and Peter Willmott (1987), which shows the rise of new forms of sociability that are better aligned with friendship than kinship. All this is reflected in more global popular sentiment where television programs such as Friends, Girls, and Sex and the City effectively promoted the ideals of friendship as the authentic modern relationship long before the advent of social media.

In all of these cases we need to remain aware that we are talking here about ideals and not necessarily practice. Allan and Pahl, who have made extensive studies 
of friendship in Britain, constantly point out that these are far removed from the idealization of pure voluntarism. Friendships in practice are highly structured by parameters such as class and gender. Peel, Reed, and Walter (2009) note there is quite a distance between the utopianism of friendship portrayed in these television series and alternative dystopian views expressed by sociologists such as Robert Putnam (1995) and Richard Sennett (1998) regarding the transience of intimacy and wider forms of engagement. Ray Pahl and David Pevalin (2005) also suggest that the development of choice in the British context as reflected by the idealization of the category of kinship within friendship in some ways strengthens kinship in our society. If one uses the ideology of friendship to claim that this individual is not just one's mother but also the person one would choose as a close friend, this is not the end of kinship but a realignment of kinship to integrate it within contemporary ideals of authenticity based on liberal choice.

To conclude this introduction, the argument is that today we find increasing evidence for a phenomenon that could be termed fictive friendship on analogy with earlier discussions of fictive kinship, in as much as it refers to cases where, as in our original example of South Park, we see kin relations being subsumed within or expected to use the idiom of friendship. This is the context for the way social media itself now subsumes kin relations by expecting kin to friend each other. The reasons for this shift lies in the way the terms kinship and friending are used as ideology to reflect the competing values of choice and obligation where choice is understood as the new possibilities of modernity, opposed to the rule-based obligations of tradition. None of this reflects the current understanding by anthropologists of either kinship or friendship as the practice of relationality. But in turn, such studies of practice do not detract from the more simplistic and dualistic colloquial use of these terms within ideology.

The primary evidence for this essay will be derived from three sources. The initial idea came from a study carried out between 2007 and 2010 working with Filipina mothers based in England who used media to reconstitute their role as mothers to the children they had left behind in the Philippines. The second research was carried out in 2011-12 in Trinidad and examined the impact of webcam, most commonly Skype, on relationships (Miller and Sinanan 2014). These ideas were confirmed and extended in a subsequent comparative study of social media in nine field sites around the world undertaken by nine anthropologists (Miller et al. 2016). Within that study, I carried out a single ethnography from 2012 to 2014 of social media in a dual village north of London (Miller 2016), which is a settlement surrounded by fields generally considered as two villages, overlapping at one corner.

\section{How friendship dominates kinship as a modern idiom}

The initial confrontation with evidence that friendship was increasingly encroaching upon kinship as an idiom for relationships came from a study from 2007 to 2010 of transnational relationships within Filipino families. We worked initially with mothers in England and then traveled to the Philippines to interview their children (Madianou and Miller 2012). One of the key findings was that Filipina mothers based in England wished to use new media to resurrect their role as 
mothers, ruptured by many years of separation from children who had grown up in their absence. For the mothers, this meant returning to a relatively formal kinship role with traditional rights and responsibilities. Texting, social media, and webcam could be used not only for constant contact but also surveillance and authority. By contrast, their children often argued that their mothers' assumptions about the power and efficacy of new media to recreate motherhood were mistaken and that in several respects the main result of renewed contact was to provide further evidence for the disparity between the mothers' claims to understand their children as against the child's situation in the Philippines. For example, the children noted that the presents they received were often more suited to children younger than their actual age. In response, the children often used the fact that they were much more fluent with new media than their mothers to create barriers and mediation between them and prevent this reimposition of authority as they saw it.

It was, however, possible to overcome this discrepancy if the mothers, in effect, ceded authority to these grown-up children and allowed the relationship to develop on more equal terms. For example, one child in the Philippines found that they had to take responsibility for organizing the care of their mother's treatment for cancer in California, and even for advising her absent father's new wife on care for their new baby. But the way this relationship progressed-e.g., afternoons having fun shopping together with her mother online from their respective computers in the Philippines and California-allowed for an increasing use of the idiom of friendship. Since friendship implies a more egalitarian and voluntaristic element, it also meant that the parents were thereby demonstrating respect for what in this case was the huge contribution of care being made by the child. This was the most extreme example, but in more muted form there were many cases where using the idiom of friendship for a parent-child relationship helped partially to resolve the conflicting viewpoints about the parent-child relationship. Rather than dispute a relationship of parenting, which is intrinsically hierarchical, mothers and their children could try and bond as "best friends" or at least as "friends."

The context for this is the general shift in power between the generations, which follows when children grow up and obtain economic as well as other forms of independence and a subsequent decrease in their dependency. But this has always been the case as children age. The important point is that the use of the idiom of friendship is a radical shift away from the traditional manner by which parental relationships remained subsumed under the idiom of kinship. In Tagalog there is a particularly powerful concept called utang na loob (Madianou and Miller 2012: 99-101; Lynch and Guzman 1974) that implies that a child is always in debt to the mother who gave birth of them irrespective of age or changes in their material relationship. This is a region where the emphasis upon kinship ideology was particularly pronounced. Under these circumstances the replacement of this ideal by the use of a symmetrical relationship such as friendship to subsume the parental relationship represents a radical shift in ideology.

In this instance, the use of new media to overcome transnational separation helped create the conditions for accepting this change. The same conditions were found in the second ethnographic project, research between 2011 and 2012 that examined the impact of webcam on relationships in Trinidad (Miller and Sinanan 2014). If the Filipino case study showed the positive potential of using friendship 
to shift the relationship from obligation to choice, then Trinidad exposed a greater range, including more negative instances.

For example, Emily (in her early twenties) talked to her parents together over webcam while she was working as a volunteer in Haiti. She would describe her day, the differences she found in the culture, and the difficulties and frustrations of doing volunteer work. Her mother would be the more active discussant, asking questions and counseling her; meanwhile, her father would just listen, sometimes sitting at the computer with her mother, at other times, sitting on his armchair watching the television on mute. For Emily's father, not looking at Emily on the screen but just hearing her voice as though she was talking to her mother in the room, was more reminiscent of how things used to be when she was at home. Mainly, he wouldn't ask if she was well or if she'd eaten and if she was taking care of herself, because these questions would force him to confront the distance created by her living abroad, and acknowledging that the stakes were much higher than when they were living together. It was clear that Emily's father worried a great deal about such issues, but he had always been more of the silent support. As a result, Emily's mother would often have to deal with her husband's anxiety once the Skype call had ended, when he would express all his fears.

These respective roles of mother and father were experienced as complementary and effective when Emily was at home, where a mother could be more emotional and immediate and a father more considered and detached. But transnational separation and webcam exacerbated the distance the father feels from his daughter to a point where he feels disconnected and frustrated. It no longer seemed to reflect the affective relationship the father desired. The additional, more voluntaristic elements in the relationship allowed his wife to develop a deeper sense of friendship, but he just felt more alienated and has no purchase on this friendship idiom, which was not a characteristic of the traditional disciplinary role of fathers in the family. The problem was quite general. It is well established that in Caribbean families, the position of the father (with its history of often absent baby-fathers) is often far more fragile than that of the mother (see Clarke 1999; Chevannes 2001).

Emily and her father were aware of these consequences and when she returned from abroad and lived at home with her parents for a few months before moving out again, both Emily and her father deliberately intervened to rescue the situation. "Daddy asked was there anything I particularly missed while I was away, then he would say, 'come on then, let's go to the mall, I'll treat you to lunch', and I could see he was quite happy to share the company and eat without necessarily having a conversation." Clearly her father recognized that he had to make at least some concession to the new idiom of friendship rather than just paternal authority.

This was not the first time I had encountered this ambiguity of kinship and friendship in Trinidad. Even in my first study of the internet in Trinidad, carried out in 1999, it was found that the people who occupied the various types of cousin became a pool of potential relationships that might or might not be realized as a close, sustained, and affective relationship, depending on either issues of instrumentality, such as going into business together or needing to stay with a relative to attend college, or simply close friendship. Some cousins become key friends, while others, who were equally close in kinship terms, remained sidelined as mere kin. The historical context is crucial here. In Modernity (Miller 1994), I suggested that 
given the legacy of slavery and the subsequent value this put on the expression of freedom, people tried wherever possible to accentuate the voluntaristic over the obligatory aspects of a kin relationship. This was also the reason why in Trinidad couples historically tended to forgo marriage notwithstanding tremendous pressures from the church toward formal marriage.

The point made in this comparison between the Philippines and Trinidad is that even if we focus on ideology rather than practice, anthropologists would still expect a relativistic approach to the historical and cultural context of ideology. So voluntarism in relationships has very different connotations in Trinidad than in the Philippines. Similarly, Nichola Khan has discussed the category of chakar among the Pakhtun, which again indicated the idiom of friendship within kinship. The description of this as a "context for escaping the bonds of kinship within the boundaries of kinship" (2014: 468) is analogous to the situation just described for Trinidad, but the reasons given in Khan's essay are entirely different from the particular historical conditions of Trinidadian society. There are both global and local factors behind the overall trend that this essay is exploring.

These examples also show that such conflations of kinship and friendship are nothing new. But with the rise of media such as webcam, Trinidadians found ways of taking this even further. What had long been the case with cousins was now becoming more important for both parent child relationships and also for sibling relationships. When siblings were living in separate countries, the degree of intensity of that relationship became much more dependent upon the specific sense of affinity and friendship that existed. Female siblings may create extremely tight bonds, as previously experienced when living together, with many tears and gestures of comfort, but the idiom of friendship helped create a new ideal of authenticity to the relationship that partly suspended the prior sense of mutual obligation given by the category of being sisters. This is perhaps even truer for brothers.

Jules (who lives in Trinidad) has one older half-brother who is ten years older than him and lives in Miami. They haven't lived in the same city since Jules was nine and they have mostly kept in touch by phone until two years ago, when Jules got his laptop. In addition to checking in and making sure the other is all right, the main thing Jules and his brother share over webcam is their passion for music, composing, and song writing. Jules is working part-time performing in a band, and his brother is a producer, so they use webcam to workshop with each other. "If he just have to hear something because I does sing too, I does record music, so if it is I have to sing piece of a song for him to hear, I could just use the webcam and show it, he could see I'm playing the guitar as well, or the keyboard, and he will see it live and stuff, just to get his comments, just to get his views on it." Jules' brother has a wife and a small daughter in Miami, so it's unlikely he will move back to Trinidad, so for Jules, it is music as the common interest that allows them to spend time together (rather than just talking).

The case is quite typical in two respects. First, webcam, and indeed new media in general, is hugely important in repairing the rupture to family life created by transnational migration. This matters in an island community where the majority of families may be transnational at the nuclear level, with a parent, child, or sibling living abroad (Miller 1994). In addition, the use of media allowed for shifts in the experience of the relationship. Instead of being juxtaposed by default in the 
same home, contact through media may be more elective, and as in this example with music, can hone in on that which works well in the constitution of friendship. Things could flow both ways. Female siblings might argue that are not just best friends but closer than any other best friends could be because they are sisters. In effect, they are asserting what is now seen to be the positive in kinship-its intimacy-while using friendship to diminish the emphasis on obligation.

So far this essay has exploited transnational distance to bring out certain qualities of this subsuming of kinship within friendship more clearly. In the third case study, however, set in a village in England, there is no such separation, and we see a kind fictive friendship as merely commonplace. But it remains true that new media-in this case social media, to be specific-helps to clarify and extend these conflations.

\section{Goldilocks and the English village}

This ethnography was carried out in a dual village with a combined population of around 17,500, situated to the north of London. It is a predominantly middle-class field site with almost no migrant or minority populations. Because the context was a comparative study of social media, the emphasis was the specificity of English usage of social media. In general, it seemed that people in this village were at first beguiled by the potential that is implied by social media for a return to community and lost friendship. This was explicitly suggested by platforms with titles such as "Friends Reunited," which were commonly used by villagers. But after reconnecting with these lost contacts, many villagers admitted that they mostly came to regret this degree of more intense sociality that threatened traditional boundaries between the private and the public that have been central to English sociality for centuries.

They therefore devised what I have termed a Goldilocks strategy, which reconfigured social media into a very English ethos of keeping people at just the right distance. This mode of usage was present in the other eight simultaneous ethnographies, but never to the same extent as in the English village. One of the key points about the Goldilocks strategy is that it can equally well apply to family as to friendship. For example:

I've got a couple of cousins; one is in Wales one is in Blackpool. They have just recently come back into my life cos my mum died and they came to the funeral. And we just keep in touch cos it's just so easy to put something on Facebook. But I probably wouldn't pick up the phone and talk to them, probably haven't got that much in common to sit and talk for half an hour. But a comment on their Facebook or a text is so much easier. I can now see her daughter, her daughter's children, and her other daughter, she's got pictures of my family. We write comments occasionally to each other on Facebook. But I don't think I'd pick up the phone and talk to her. I think as you get older you have less and less family and you grab hold to what you have got. Cos she hasn't got parents. Got one brother. And I'm her only cousin. We've all of a sudden, she's got like a friend. 
Keeping people at the appropriate distance is a very common strategy with regard also to the problem of neighbors who again should be close-but not too close. When Peggy's husband was dying, "We had neighbors in, a young couple across the road would come in. They were religious. They were trying to pressurize me and I don't want that." After he died, there were plenty of visitors and condolences immediately after the death. But these all seemed to dry up at a time when really Peggy still needed them. So, she found sharing on Facebook with others who were talking about how it felt to be bereaved was quite helpful. Living alone, Peggy can watch TV, but then she gets itchy fingers and wants to "tap" away on Facebook. She is careful to explain that she is not addicted to Facebook, but she wonders what the kids have been doing, or if there is any news from her sister. She tried a game with her brother but didn't persevere. She likes that her brother scans and posts pictures he had found that were kept by their mother, so that now all the family can post about how awful everyone looked. She sees the postings of both her sons and it doesn't matter too much if they are a bit daft on occasion. Knowing what her son is up to, she is also able to predict when he is likely to come over with a bag of dirty washing, on his way to his girlfriend. Again she doesn't mind too much. Sometimes she goes a bit further. In fact, she quite surprised herself when she posted asking if anyone knew how to put up a trellis for her garden; after all, there is no way she would have gone on the road and asked a stranger or even a neighbor that question. So now a friend of her late husband is going to help her with it. Mind you, she is a bit more upset by some of the bad language and people venting in public, or some quarrels reflected in "indirects."

As illustrated by this example, the Goldilocks strategy is adept at dealing with the mundane trivial that is the substance of the sustained sociality of everyday life, but may also be employed to help deal with major issues of death and condolence and forming new relationships. This is particularly clear to Peggy with respect to her most difficult current relationship, which is with her four-year-old granddaughter. Her son is estranged from his wife-very estranged-so Peggy has no direct contact at all with her granddaughter. Her son had separated even before the mother realized she was pregnant. They tried getting back together but it ended even more acrimoniously and now he won't go around there ever. So just like her, his son never actually sees his daughter at all. All his knowledge of the daughter comes through Peggy's Facebook. She is a Facebook friend with her daughter-inlaw and every time there is a new photo of her granddaughter she downloads it to show to her son. Her daughter-in-law knows perfectly well that this is going on and approves. For Peggy, on the one hand this is all pretty heartbreaking but it's the best she can do in the circumstances. And for all concerned, it provides an ideal example of social media's amazing ability to keep people both connected and keep them apart at the same time, which-given the extent of divorce and the rise of "complex" families in contemporary Britain-is now a significant facility.

There are also quite problematic consequences of this Goldilocks strategy. This research included a day a week working with patients at a hospice. In a separate paper (Miller 2015), I provide evidence to show how this subsuming of kinship under the ideology of friendship has negative repercussions for the elderly and the dying. They, too, now regard the relationship between kinship and obligation negatively. Again and again they reiterate that they don't want to be a burden on their family. 
Indeed, in some cases they actively discourage being visited, telling their family that there are more important things than visiting them. A typical statement about the relation to one's family is, "We don't wish to impose. ... We avoid it. If they need help I'd go to any lengths to do it. But generally speaking we don't interfere." But this same shift becomes a reason why they are subsequently neglected. During the advanced stages of cancer they need more help, but since neither side want to stress any obligation to visit, they often don't receive that help. This is as much because the patient declines the offer of a visit as because it is less clear to relatives that they are obligated to provide help. The paper on this topic is called "The tragic dénouement of English sociality" because the central point is that the surprising degree of isolation and loneliness among terminally ill patients in a rural setting was not the result of the decline of traditional English sociality, it was because of the persistence of this particular form of English sociality.

At the same time, there is a shift toward the adoption of friendship as an idiom for kinship found in both parenting and grandparenting relationships and now facilitated by the increasing use of Facebook. Surprisingly, elderly English informants were quite tolerant of this new direct exposure to the culture of teenagers' internal interactions to which they were now exposed by way of becoming Facebook friends. It is unlikely that there is any precedent to this ability of older people to have such direct access to the observation of peer-to-peer friendship behavior among the young. Wang (2016: 107-9) has also explored this phenomenon in China where she argues the symmetrical point that young Chinese people have suddenly also a direct experience of the way older "seniors" in their family behave on social media such as WeChat. This, in turn, helps them to see such senior figures in a new light and in effect humanizes them, thereby once again shifting the formal category and experience of kinship authority toward something more like friends.

There is then almost no aspect of kinship that remains outside of this increasing conflation with idioms of friendship. In the English village, this even extends to the creation of ancestral relationships. One of the major impacts of social media is on death and memorialization. It was evident that people have become frustrated by the formality of conventional responses to death inherited from religious ritual. As the authenticity of true relationships - now including family relationships-migrates to the idiom of friendship, people want an element of the spontaneous and humorous banter in relation to the dead that for them signifies real friendship, which religious rituals, such as visiting the grave, did not provide. As a result, it is now common to see social media such as Facebook used as memorial sites for the departed. This means people can make comments or express grief when they feel like it, rather than when it is expected of them. They can now also include humor and anecdotes about the deceased to show their genuine affection. This spread in the ideology of friendship to incorporate kin relationships may also now include the desire to be friends with one's ancestors.

This then brings with it problems and new sources of embarrassment, as people are unsure as to what is appropriate within this new mode and normativity is harder to ascribe, for example:

Funnily enough I always get an instinct when it's the anniversary of my mum's death. Because I don't have wider family. It's the kind of day that 
can go by without any reference to my mum ever having existed. It's like, I always feel tempted to put something. Like it's 8 years since my mum died. But you know when you think it's such a public setting. There's 136 people here. This is the kind of thing I'd talk to my friends about but I don't necessarily, the world and his wife. It's too precious to have it spread across 136 acquaintances who I haven't seen for years and some of them that are just school friends.

The ambiguity is also there in the offline world. Today, informants in the village quite often introduce others as "my mum, my brother, my cousin, etc." but then add to that, "also my best, my close friend, etc." It is clear from these expressions that the use of friendship as ideology allows people to create relationships that are more in tune with general changes in our understanding of authenticity within relationships. For younger informants, friendship has itself become almost fetishistic with lives revolving around categories such as "bestie" and "BFF" with traumatic highs and lows as the Best Friend Forever argues with you and becomes the BFF of your worst enemy, partly through gifting your secrets to her.

Initially, journalists like to claim that young people might not have the capacity to tell whether a Facebook friend was a "real" friend. Not surprisingly, more empathetic ethnography with such young people suggests quite the opposite. Even offline, the category of friendship is constantly dissected with forensic precision. The implications are regionally specific, as are the semantics. In Trinidad, the verb "to friend" had previously meant to be involved in a sexual relationship, while in Brazil it is the term one uses to greet the waiter in a restaurant (Rezende 1999). But in every case people seem clear as to the nuances that surround the term friend whether as noun or verb.

All of which then brings us back full circle to the final source of ambiguity, which was raised by the initial example taken from South Park. If kin are now being routinely incorporated into friendship, most literally in the act friending on Facebook, does this also represent a shift toward certain forms of obligation that are retained as central to the ideology of kinship, rather than just the one-way traffic toward the voluntarism represented by the ideology of friendship?

In this case, there is an iconic moment when the dilemma became quite explicit. Villagers vividly recall the moment when "my mother asked to friend me" on Facebook. Suddenly everyone became highly conscious of the way kinship had become interpolated into friendship. The dialogue of South Park then seems quite predictable. Once mothers became friends on Facebook there is rapid shift in the very meaning and experience of Facebook itself. Facebook was once a cool peer-to-peer network for the young but has become a slightly oppressive place of family obligation, as in the case of Stan. My ethnography documented the shift whereby young people therefore transferred their peer interactivity to other spaces outside of adult surveillance, such as Twitter. In the space of two years, Facebook moved from being a platform where anxious parents sometimes tried to prevent their children joining, to the scenario now commonly reported by school pupils, which is that it is their parents who insist that they should remain on Facebook in order to stay connected with their family. Facebook was certainly important in reflecting this wider expansion in the ideology of friendship increasingly incorporating traditional kin relations. But this came with a cost, because there was a retained legacy of obligation 
associated with the ideology of family relations. This was sufficiently powerful in that it is the main explanation for a trend documented within the ethnography of Facebook in an English village. This revealed a decline in the use of Facebook itself among young people, who now see it as precisely a place for communication with relatives rather than the cool peer-to-peer platform for peers (which has now shifted to sites such as Snapchat and Twitter).

As shown by this last example, the arguments of this essay are far from an exercise in technological determinism. Facebook is not a cause. Rather this account reverses the direction of explanation. Instead, we can now appreciate how the transformation of the term friend into a verb accords with these wider trends in friendship as ideology, as implied by the title of our comparative book, How the world changed social media (Miller et al. 2016). Indeed, as suggested by the original example of South Park, the contradictions that follow from this conflation of kinship and friendship remain so powerful that it creates this loss of cool for Facebook as a platform. The way young people shifted to other platforms such as Twitter and Snapchat for their peer-to-peer interactions was in direct repudiation of the power and desires of the company that owns Facebook, which has been desperate to retain those initial associations with youth. The degree to which the Facebook company has been thwarted by this trend is strong evidence that it is these underlying shifts in ideology and practice as studied by anthropologists that remain crucial to appreciating current developments in media and sociality, not merely the study of the companies and their interests.

\section{Conclusion}

The essay began with a careful separation. On the one hand, we acknowledge the development of an increasingly sophisticated anthropological conceptualization of both kinship and friendship as forms of practice under the more general auspices of the comparative study of relationality. Yet, it is possible to simultaneously acknowledge that at the level of ideology there is a much more simplistic and dualistic use of these terms by these informants. They may blithely ignore the subtleties and contradictions of practice because these terms are now very convenient idioms for expressing the ideal that modern relationships should reflect the authenticity and informality that are the supposed results of choice rather than the obligations associated with the past and tradition. Clearly this ideology of kinship and friendship can and does impact upon the practice of kinship and ideology as well as vice versa, but we also find considerable autonomy between these two, as implied by Bourdieu's original work on the discrepancy between kinship as practice and kinship as rule.

This is also an important point for comparative anthropology. It is very likely that with the rapid spread of popular culture-including social media-we see a tendency to homogeneity when it comes to kinship and friendship as ideology, as in the constant reiteration of the cliché "you can choose your friends but you can't choose your relatives" across entirely dissimilar field sites. Another example can be found in the way a verb "friending" has become acceptable alongside the massive use of Facebook because Facebook has thereby simply made explicit the more 
general trend described and analyzed in this essay. Yet, this global spread of an ideology of friendship is subject to localized interpretation just as is the practice of friendship. A key finding of the Why We Post project was that a new social media platform could spread across the world in months, but in that same short period it can be subject to such a degree of localization as to become ultimately an instrument for growing heterogeneity rather than homogeneity (Miller et al. 2016).

There are therefore no arguments in this essay that should detract from the continued research of anthropology on the nuances of kinship or friendship as practice, which includes a greater emphasis upon cultural difference. For example, Simon Bell and Sandra Coleman (1999a) include a paper by Claudia Rezende (1999) that examines other ways the term friend is used idiomatically in various societies, as in Brazil where it expresses an ideal of affinity, or China where it is related to the wider concept of guanxi (Smart 1999). As already noted, the use of friendship as an idiom can also be used to help repair the ruptures to kinship. For example, Costa observes how Facebook is used to renew contacts with dispersed lineages and tribes among Kurdish populations (Costa 2016: 88-94), helping people to return to traditional forms of group sociality despite the dispersal that has resulted from political violence.

This essay has at its core a shift in ideology, such that an older tendency to subsume friendship within kinship termed fictive kinship is now replaced by a tendency at the level of ideology to subsume kinship within the dominant idiom of friendship. Today we encounter a profusion of contexts in which parents, children, siblings, and other relatives feel it is essential to couch their kin relationship in terms of the ideal that they are also close or best friends. At the level of ideology, kinship itself is having to be realigned to accord with what people from China and many other areas now see as the modern values of authenticity, informality, and sentiment as part of a liberal ethic of choice, which they regard as better expressed through the supposed voluntarism of friendship. It seems essential, therefore, that anthropology pays as much attention to this trajectory in the ideology of kinship and friendship as it does to teasing out the contradictions and nuances of kinship and friendship as practice.

\section{References}

Allan, Graham A. 1979. A sociology of friendship and kinship. London: George Allen and Unwin.

1989. Friendship: Developing a sociological perspective. Hemel Hempstead: Harvester Wheatsheaf.

Baltzly, Dirk, and Nick Eliopolous. 2009. “The classic ideals of friendship.” In Friendship: A history, edited by Barbara Caine, 1-64. London Equinox.

Beck, Ulrich, and Elisabeth Beck-Gernsheim. 1995. The normal chaos of love. Cambridge: Polity.

Bell, Simon, and Sandra Coleman, eds. 1999a. The anthropology of friendship. Oxford: Berg. 
1999b. "The anthropology of friendship: Enduring themes and future possibilities." In The anthropology of friendship, edited by Simon Bell and Sandra Coleman, 1-20. Oxford: Berg.

Bourdieu, Pierre. 1968. Outline of a theory of practice. Cambridge: Cambridge University Press.

Carsten, Janet. 1997. The heat of the hearth: The process of kinship in a Malay fishing community. Oxford: Clarendon Press.

Chevannes, Barry. 2001. Learning to be a man: Culture, socialization, and gender identity in five Caribbean communities. Kingston: University of the West Indies Press.

Clarke, Edith. 1999. My mother who fathered me: A study of the families in three selected communities of Jamaica. Kingston: University of the West Indies Press.

Comaroff, John L., and Simon Roberts. 1981. Rules and processes: The cultural logic of dispute in the African context. Chicago: University of Chicago Press.

Costa, Elisabetta. 2016. Social media in southeast Turkey. London: UCL Press.

Course, Magnus. 2010. "Making friends, making oneself: Friendship and the Mapuche person." In The ways of friendship, edited by Amit Desai and Evan Killick, 154-73. Oxford: Berghahn.

Desai, Amit. 2010. "A matter of affection, ritual friendship in central India." In The ways of friendship, edited by Amit Desai and Evan Killick, 114-32. Oxford: Berghahn.

Desai, Amit, and Evan Killick, eds. 2010. The ways of friendship. Oxford: Berghahn.

Dousset, Laurent. 2013. "From consanguinity to consubstantiality: Julian Pitt-Rivers' "The Kith and the Kin." Structure and Dynamics 6 (1). http://escholarship.org/uc/ item/4fr203tx.

Finch, Janet, and Jennifer Mason. 1993. Negotiating family responsibilities. London: Routledge.

Firth, Raymond. 1956. Two studies of kinship in London. London: Athlone Press.

Freed, Stanley A. 1963. “Fictive kinship in a north Indian Village.” Ethnology 2 (1): 86-103.

Giddens, Anthony. 1991. Modernity and self-identity: Self and society in the late modern age. Cambridge: Polity Press.

Froerer, Peggy. 2010. "Close friends: The importance of proximity in children's peer relations in Chhattisgarh, central India." In The ways of friendship, edited by Amit Desai and Evan Killick, 133-53. Oxford: Berghahn.

Heath, Anthony Francis. 1981. Social mobility. London: Fonatana.

Khan, Nichola. 2014. "The taste of freedom: Commensality, liminality, and return amongst Afghan transnational migrants in the UK and Pakistan." Journal of the Royal Anthropological Institute 20 (3): 466-85.

Killick, Evan. 2010. "Ayompari, compadre, amigo: forms of fellowship in Peruvian Amazonia." In The ways of friendship, edited by Amit Desai and Evan Killick, 46-68. Oxford: Berghahn. 
Killick, Evan, and Amit Desai. 2010. "Introduction: Valuing friendship." In The ways of friendship, edited by Amit Desai and Evan Killick, 1-20. Oxford: Berghahn.

Lindholm, Charles. 2013. “The rise of expressive authenticity." Anthropological Quarterly 86 (2): 361-95.

Lynch, Frank, and Alfonso Guzman. 1974. Four readings on Philippine values. 4th ed. Quezon City: Ateneo de Manila Press.

Mac Rae, Hazel. 1992. "Fictive kin as a component of the social networks of older people." Research on Aging 14 (2): 226-47.

McDonald, Tom. 2016. Social media in rural China. London: UCL Press.

Madianou, Mirca, and Daniel Miller. 2012. Migration and new media: Transnational families and polymedia. London: Routledge.

Misztal, Barbara. 2000. Informality: Social theory and contemporary practice. London: Routledge.

Miller, Daniel. 1994. Modernity: An ethnographic approach. Oxford: Berg.

—. 2015. "The tragic dénouement of English sociality." Cultural Anthropology 30 (2): $336-57$.

- 2016. Social media in an English village. London: UCL Press.

Miller, Daniel, and Jolynna Sinanan. 2014. Webcam. Cambridge: Polity.

Miller, Daniel, Elisabetta Costa, Nell Haynes, Tom McDonald, Razvan Nicolescu, Jolynna Sinanan, Juliano Spyer, ShriramVentkatraman, and Xinyuan Wang. 2016. How the world changed social media. London: UCL Press.

Norbeck, Edward, and Harumi Befu. 1958. "Informal fictive kinship in Japan." American Anthropologist 60: 102-17.

Okada, Ferdinand E. 1957. "Ritual brotherhood: A cohesive factor in Nepalese society." Southwestern Journal of Anthropology 13: 212-22.

Pahl, Ray. 2000. On friendship. Cambridge: Polity.

Pahl, Ray, and David J. Pevalin. 2005. "Between family and friends: A longitudinal study of friendship choice." The British Journal of Sociology 546 (3): 433-50.

Paine, Robert. 1999. "Friendship: The hazards of an ideal relationship." In The anthropology of friendship, edited by Sandra Bell and Simon Coleman, 39-58. Oxford: Berg.

Peel, Mark, Liz Reed, and James Walter. 2009. “The importance of friends: The most recent past." In Friendship: A history, edited by Barbara Caine, 317-55. London Equinox.

Putnam, Robert. 1995. Bowling alone. New York: Simon and Schuster.

Rezende, Claudia. 1999. "Building affinity through friendship." In The anthropology of friendship, edited by Sandra Bell and Simon Coleman, 79-98. Oxford: Berg.

Sahlins, Marshall. 2011. "What kinship is (part one)." Journal of the Royal Anthropological Institute 17: 2-19. 
Sennett, Richard. 1988. The corrosion of character: The personal consequences of work in new capitalism. New York: Norton.

Smart, Allen. 1999. "Expressions of interest: Friendship and guanzi in Chinese societies." In The anthropology of friendship, edited by Sandra Bell and Simon Coleman, 119-36. Oxford: Berg.

Stasch, Rupert. 2009. Society of others. Berkley: University of California Press.

Tierney, William. 2006. "The role of peer groups in applying and paying for college." American Behavioral Scientist 49 (12): 1687-1702.

Wang, Xinyuan. 2016. Social media in industrial China. London. UCL Press.

Weeks, Jeffrey, Brian Heaphy, and Catherine Donovan. 2001. "Same sex intimacies: Families of choice and other life experiments." London: Routledge.

Willmott, Peter. 1987. Friendship networks and social support. London: Policy Studies Institute.

Young, Michael, and Peter Willmott. 1975. The symmetrical family. Harmondsworth: Penguin.

\section{Idéologie de l’amitié à l'ère de facebook}

Résumé : Cet article suggère que tandis que les anthropologues ont développé une analyse très nuancée des rapports de parenté et d'amitié dans le cadre d'une analyse comparative générale de la relationnalité, l'accent mis sur la pratique requiert d’être complété par un autre angle d'approche se concentrant sur les usages des termes en question en tant qu'idéologie, idéologie par laquelle nous pouvons accéder à un usage plus simpliste et dualiste de ces rapports. L'émergence de nouveaux réseaux sociaux et le verbe anglais 'to friend' révèle un changement général d'une idée de parenté fictive à celle d'amitié fictive, où les idéaux représentés par le volontarisme et l'authenticité présumés de l'amitié dominent la manière dont les gens perçoivent actuellement les rapports de parenté. Des exemples tirés de travaux ethnographiques menés aux Philippines, à Trinidad et en Angleterre illustrent la prévalence d'une pratique où les rapports de parenté sont décalés et exprimés dans le lexique de l'amitié, impliquant des conséquences positives et négatives. Cette incorporation de la parenté au sein de l'amitié peut également faire prévaloir un sens renouvelé des règles et des obligations, ce qui a mené à une diminution de l'usage de Facebook par les jeunes.

Daniel Miller is Professor of Anthropology at University College London. Recent books include The comfort of people (Polity, 2017), Visualising Facebook (with Jolynna Sinanan, UCL Press, 2017), How the world changed social media (with eight others, UCL Press, 2016), Social media in an English village (UCL Press, 2016), Webcam (with Jolynna Sinanan, Polity, 2014), Blue jeans (with Sophie Woodward, University of California Press, 2012), Digital anthropology (edited with Heather 
Horst Berg 2012), Migration and new media (with Mirca Madianou, Routledge, 2012), and Consumption and its Consequences (Polity, 2012).

Daniel Miller

Department of Anthropology

University College London

14 Taviton Street

London WC1H OBW

d.miller@ucl.ac.uk 